\title{
Cancer Susceptibility Candidate Protein 1
}

National Cancer Institute

\section{Source}

National Cancer Institute. Cancer Susceptibility Candidate Protein 1. NCI Thesaurus. Code C112056.

Cancer susceptibility candidate protein 1 (716 aa, $\sim 83 \mathrm{kDa}$ ) is encoded by the human CASC1 gene. This protein may play a role in the pathogenesis of certain types of cancer. 